\title{
INTERNAL STRUCTURE OF FAULT ZONES: SPATIAL AND TEMPORAL EVOLUTION STUDIES ON CLAY MODELS
}

\author{
K. Zh. Seminsky \\ Institute of the Earth's Crust, SB RAS, Irkutsk, Russia
}

\begin{abstract}
Based on results obtained from experiments on clay models, it appeared possible to establish main regularities in the evolution of normal and strike-slip zones which structures are formed heterogeneously in time and space. The spatial heterogeneity is reflected in the regular pattern of the fault zone structure due to the fact that sectors of two different types are length-wisely alternating in the fault zone. Within sectors of Type 1, the main fault forms rapidly. Sectors of Type 2 are characterized by the long-term evolution of the pattern, significant width and high densities of fractures; in final development phases, they are represented by relay structures. The temporal heterogeneity is manifested by stages and sub-stages in the development of the fracture network, which are closely interrelated. Each of the three main stages is associated with specific deformational behaviour of the medium and a particular type of the fracture pattern, as suggested by results of our tectonophysical modelling of fracturing. The model is presented in the article; it is supported by data on natural normal and strikeslip faults.
\end{abstract}

Key words: strike-slip fault, normal fault, clay model, fracture, spatial and temporal evolution, stage.

Recommended by M.A. Goncharov 25 June 2012

Citation: Seminsky K.Zh., 2012. Internal structure of fault zones: spatial and temporal evolution studies on clay models. Geodynamics \& Tectonophysics 3 (3), 183-194. doi:10.5800/GT-2012-3-3-0070.

\section{ВНУТРЕННЯЯ СТРУКТУРА РАЗЛОМНЫХ ЗОН: ПРОСТРАНСТВЕННО- ВРЕМЕННАЯ ЭВОЛЮЦИЯ НА ОСНОВЕ РЕЗУЛЬТАТОВ ФИЗИЧЕСКОГО МОДЕЛИРОВАНИЯ}

\section{К. Ж. Семинский}

\section{Институт земной коры СО РАН, Иркутск, Россия}

\begin{abstract}
Аннотация: На основе обобщения результатов экспериментов на моделях из влажной глины установлены главные закономерности эволюции сдвиговых и сбросовых зон, структура которых формируется неравномерно во времени и пространстве. Отражением пространственной неравномерности является регулярность в строении разломной зоны, связанная с чередованием в продольном направлении двух типов участков. В пределах участков 1-го типа сравнительно быстро формируется магистральный сместитель. Участки 2-го типа характеризуются длительной эволюцией структуры, существенной шириной, высокой плотностью разрывов и на заключительных этапах развития представлены релей-структурами. Отражением временной неравномерности является наличие стадий и подстадий развития разрывной сети, которые тесно взаимосвязаны. Каждой из трех главных стадий соответствуют строго определенные деформационное поведение субстрата и тип разрывной сети, что представлено в тектонофизической модели формирования разломной зоны, которая описана в конце статьи и проиллюстрирована примерами природных сбросов и сдвигов.
\end{abstract}

Ключевые слова: сдвиг, сброс, модель из влажной глины, разрыв, пространственно-временная эволюция, стадия. 


\section{INTRODUCTION}

The article considers general spatial and temporal regularities in faulting which are manifested in fault zones when they develop due to strike- and dip-slip movements of the blocks composing such zones. The knowledge on such regularities is fundamental for adequate understanding of many processes which accompany faulting as in certain structural conditions these regularities occur in the initial form, whereas in other cases these regularities can be used to interpret complex patterns of fracture zones varying in types and scales.

Among the general regularities, which have been established by other researchers, it is reasonable to note a typical set of the $2^{\text {nd }}$ order fractures (Fig. 1); they occur in fault zones by in-plane shear (mode III) [Kim et al., 2004]. It has been revealed that the structure evolves in stages. By comparing the Riedel experiment structure and the «force - displacement» curve, [Tchalenko, 1970] has defined three stages in formation of shearing zones. During the first peak stage, $R$ - and $R$ '-shears develop with the highest possible resistance to shearing. The second post-peak stage is characterized by $P$-shears development on the background of strain softening. During the third «residual stage», $Y$-shears occur, while resistance to shearing is nearly permanent. On the other hand, it is impossible to establish a 'force - displacement' curve for a natural situation; and the diagnostic role of $R$ - and $Y$-shears for defining the stages should be specified, taking into account that the available experimental data suggest the occurrence of $R$-shears in the peak stage and $Y$-shears in the post-peak stage [Bartlett et al., 1981; Mandl, 1988]. Therefore, it is challenging to define stages in the development of the pattern of strike-slip zones, and it is particularly difficult to define such stages for dip-slip faults which develop with the displacement vector being perpendicular to the faulting front (mode II). It is thus required to confirm that J.S. Tchalenko's concepts are universal [Tchalenko, 1970], and also to characterize the stages of faulting in a more detail.

The general peculiarity of the spatial pattern of fault zones is the existence of fracture complexes formed by bending or junction of the largest $2^{\text {nd }}$ order fractures. They are typical for the faults varying in types and scales; and with regards to details of the pattern and formation, they can be termed as transfer zone, step-over, fault-bridge, destructive fields, relay zone (or structure), duplex, accommodation zone, pull-apart, push-up etc. [Woodcock, Fischer, 1986; Lobatskaya, 1987; Sylvester, 1988; Gibbs, 1984; Kearey, 1993; Park, 1997; Walsh et al., 1999]. Regardless of the differences, these specific structures are named below as 'relay structures' [Walsh et al., 1999]. Their peculiar characteristic is that they are distinguished by high density of fractures in comparison with the adjacent sectors of the zone. Therefore, our attention shall be focused on positional relationships between the relay structures that are distinctly expressed at late development stages of the fault zone and also on such relationships' manifestation at early stages characterized by the presence of sectors wherein small Riedel's shears are highly dense.

It is proved that quantitative analyses of fracture patterns at different evolutional stages can provide for consistency and efficiency in finding solutions to the problems specified above and also in reviewing spatial and temporal peculiarities in the formation of the fault zones. In the present study, experimental modelling has been employed as the major research method (1) to reveal general regularities in stages of formation of fault zones varying in types on the basis of assessment of variations in the fracture patterns during deformation of the model; (2) to reveal general regularities in fracture density distribution at different stages of formation of strike-slip and normal fault zones' structures; (3) to present a tectonophysical model of a fault zone, which consolidates the known and newly established spatial and temporal regularities of fracturing.

\section{EXPERIMENTAL METHOD}

Our experiments are based on a rectangular homogeneous clay model (over $0.5 \mathrm{~m}$ in length and over $0.5 \mathrm{~m}$ in width) which is subject to deformation. The model's thickness $(H)$, viscosity $(\eta)$, and deformation rate $(V$, relative movements of the 'basement blocks') are maintained permanent throughout an experiment, yet differ from one experiment to another $\left(H=0.04 \div 0.14 \mathrm{~m} ; \quad \eta=6 \cdot 10^{6} \div 3 \cdot 10^{9}\right.$ Pa.s; $V=10^{-5} \div 10^{-3} \mathrm{~m} / \mathrm{sec}$ ). The methodology of such experiments is described in detail in [Sherman et al., 1983]; the referred publication introduces similarity criteria and states that the clay's elasto-plastic properties in the experimental conditions are similar to those of the earth's crust subject to faulting.

An originally designed installation called Razlom is used to study strike-slip and normal fault zones in large models made of the specially selected elasto-plastic material. The Razlom equipment provides for displacements of the model's parts in the horizontal and vertical directions and shifting with a slope, as required. Many researchers refer to similar conditions of tectonophysical modelling, as reported in [Tchalenko, 1970; Wilcox et al., 1973; Mikhailova, 1971; Sherman et al., 1983; Mandl, 1988; Guohai, Groshong, 2006; Rosas et al., 2009]. A specific feature of our approach is that in the course of each experiment the fracture pattern on the model's surface is recorded by photographs and then slightly smoothed out of the model surface; by doing so, we ensure that only active fractures are recorded in the next photos and then subject to analyses. Each experiment is conducted until the model is completely destroyed, i.e. until the model's surface is fully dissected by the major continuous rupture.

Based on the photos taken at various deformation steps, 


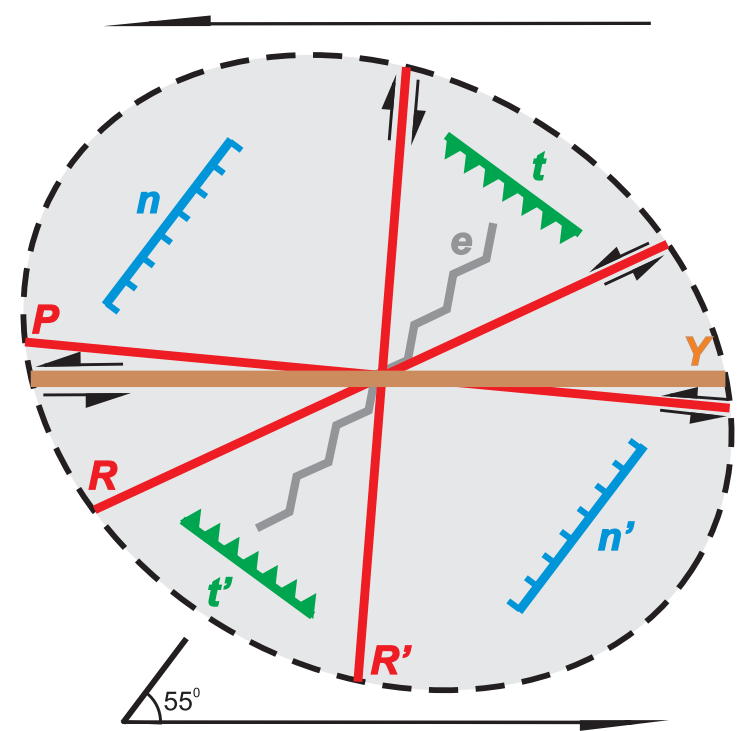

Fig. 1. Types of echelon fractures formed in shearing zone (exemplified by the sinistral strike-slip fault on the data [Bartlett et al., 1981; Mandl, 1988; Tchalenko, 1970; Wilcox et al., 1973]): $Y, R$ ', $R$ and $P$ - strike-slip faults; $n$ ' and $n$ - normal faults; $t$ ' and $t$ - reverse faults; $e$ - extension fractures.

Рис. 1. Типы эшелонированных разрывов, образующихся в зоне скалывания (на примере левого сдвига) [Bartlett et al., 1981; Mandl, 1988; Tchalenko, 1970; Wilcox et al., 1973]: Y, R', R и P сдвиги; n' и n - сбросы; t' и t - взбросы; е - разрывы растяжения.

schemes of active fractures are constructed and subject to processing and analyses as original experimental data (Fig. 2). To study temporal peculiarities of fracturing, three main parameters of the fracture pattern are evaluated: a length of the longest fracture in the zone under study $\left(L_{M}\right)$; an average width of a zone $(M)$, and a total quantity of fractures within the given sector of the zone $(N)$. To study distribution of active fractures, maps of fracture density $(\rho)$ are constructed (see Fig. 2). For all the schemes in every separate experiment, the size of the fracture density measurement grid is equal to a half of the corresponding model thickness.

\section{EXPERIMENTAL RESEARCH RESULTS}

Results of our experiments conducted in different conditions (i.e. with different values of $V, H$, and $\eta$ ) show that $R$ '-shears are recorded only at the initial steps of the models' deformation, and the model is mainly subject to destruction by evolving $R$-, $P$ - and $Y$-type fractures. In normal fault zones, these are antithetic and synthetic normal faults, whereas in strike-slip zones, vertical synthetic strike-slip faults occur. The structure of the zone of any type develops as $R$-shears grow in length and conjugate with each other via $P$-shears, and $Y$-shears occur, and, fi- nally, a single major displacement fracture is formed. Our quantitative analyses of the fracture patterns give evidence to conclude that the evolution is irregular both in time and space even in experimental conditions, despite the fact that the model is homogeneous, the force is regularly applied along a zone strike, and the rate $(V)$ is constant.

Time aspect of structure development. The first detail description of our studies of $L_{M}, M$ and $N$ variations at different stages of formation of strike-slip fault zones' structures was published in [Seminsky, 1990]. In the referred article, major visually recorded trends of temporal changes of the structure (Fig. 3, a) are quantitatively confirmed, and it is established that the zone's width and the quantity of active fractures increase at the beginning and then decrease, whereas the length of the longest fracture is steadily increasing during evolution of the fault zone. It is also revealed that synchronous short-time variations occur, and changes of the parameters are recorded in the same mode, i.e. $L_{M}$ increases sharply, and $M$ and $N$ change spasmodically. These variations are quantitative evidences of the structural transformations which demark stages in development of the strike-slip zone or long-term periods of relatively stable development of the fracture pattern.

Within each development stage, general trends in variations of the structure's parameters are maintained; nonetheless, every stage is characterized by specific interrelations between the fractures. For instance, curves showing fracture quantities versus lengths by stages in development of the fault zone (Fig. 3, $b$ ) can be grouped in several bunches corresponding to each stage, and this suggests particular correlations between fracture dimensions. In transition from one stage to another, the self-similarity mode is changed since in the course of structural transformation the bridges are destroyed to give way to the occurrence of larger fractures; at the same time, numerous small fractures, which fall into the zones influenced by such larger fractures, become passive. Thus, the structure of the strikeslip fault zone is formed irregularly in time. It should be noted that it was recorded in all the experiments that one of the transformations plays the main role: it takes place near to a maximum on the «force - displacement» curve, and it is characterized by the most abrupt changes of the parameters under study (Fig. $3 a$ ). This maximum corresponds to the moment when one of the extended fractures dissects model completely in one of its sectors, and the integrity of the model is thus significantly damaged.

Regularities of faulting established for the strike-slip faults are generally verified for normal fault zones in experiments conducted in other conditions of deformation (Table). As exemplified by one of the models (Fig. 4), deviations from the general trends of changes in the fracture pattern parameters allow us to define development stages for such conditions too. It should be noted that, unlike slipstrike faulting, development of normal faults clearly demonstrates only one structural transformation which takes place when $L_{M}$ sharply increases, whereas $M$ and $N$ are decreasing. Anyway, by using the data from article [Acker- 


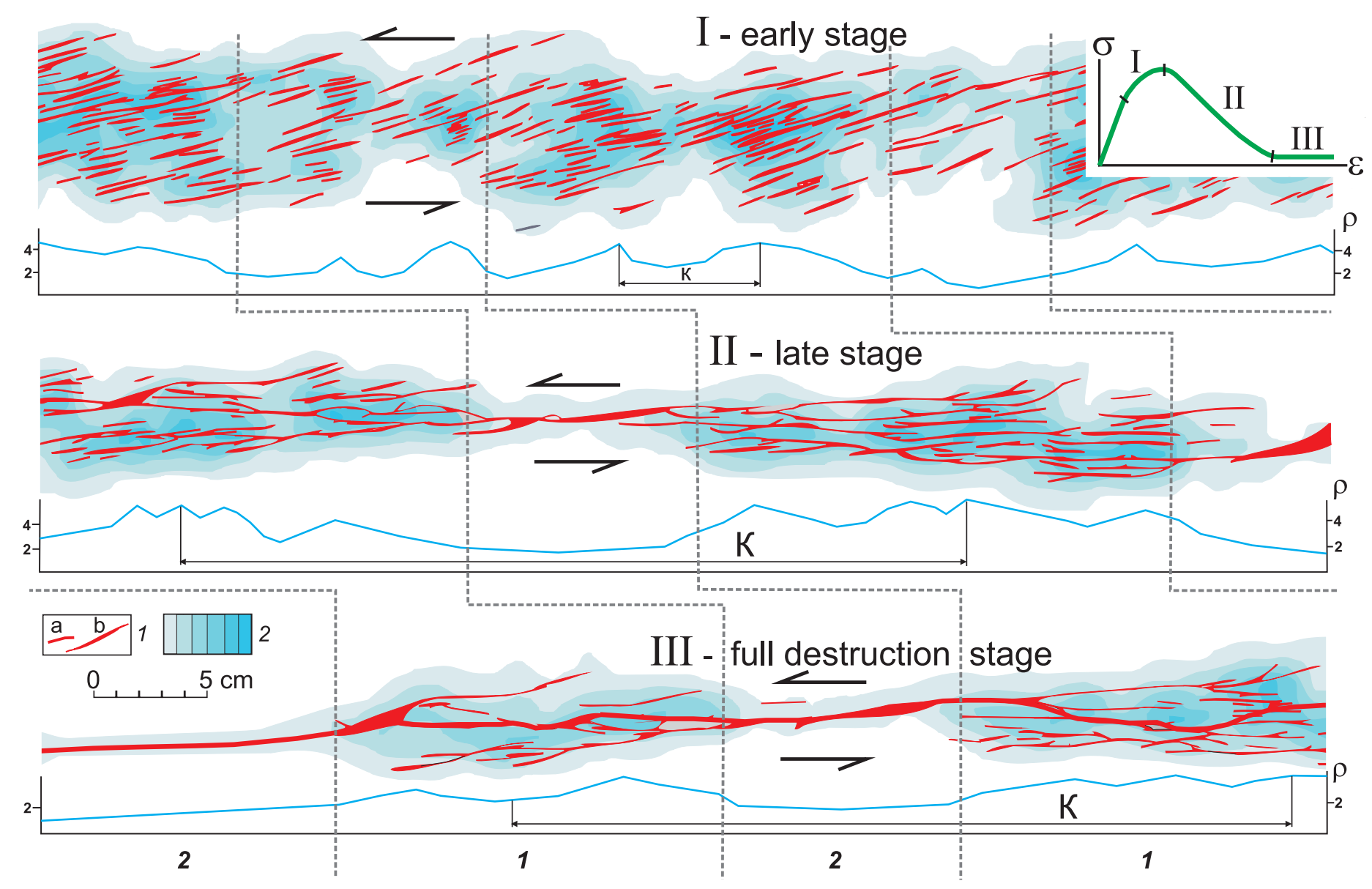

Fig. 2. Schemes of fractures, curves, and maps of fracture density $(\rho)$ in isolines corresponding to main stages of development of the strike-slip zone in the elasto-plastic model. 1 - fractures with insignificant (a) and significant (b) opening displacement component; 2 - areas with different fracture density; dotted lines - lines between structural development sectors (1 and 2); K and $\mathrm{K}$ - distance between fracture density maximums in different stages. An inset shows the basic form of the 'stress $(\sigma)-$ strain $(\varepsilon)$ ' curve for the discussed experiments.

Рис. 2. Схемы разрывов, графики и карты распределения их плотности (р) в изолиниях, соответствующие главным стадиям развития сдвиговой зоны в упруго-пластичной модели. 1 - разрывы с незначительной (а) и значительной (б) раздвиговой составляющей смещения; 2 - области с разным количеством разрывов в единице площади; пунктир - линии, разделяющие участки (1 и 2) разного структурного развития; К и к - расстояние между максимумами плотности разрывов на разных стадиях разрывообразования. На врезке - прин-

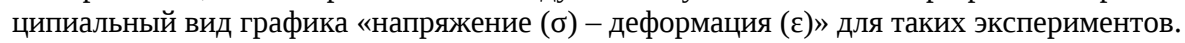

mann et al., 2001] (though such data were obtained in slightly different modelling conditions) for more detailed statistical analyses of normal fault models, it appears possible to define stages even within the earliest structure formation period. Thus, there are grounds to assume that the basic evolution character is also maintained for normal faults, though the importance of separate stages in transformation of the fracture pattern is variable.

Our experiments (Fig. 4) reveal only three indicative moments of formation of the normal fault zone structure: (1) occurrence of the first fractures, (2) main structural transformation, and (3) occurrence of the major fracture on the model surface. It is suggested that such moments occur depending on $V$ and $H$ (Table). Values of $t_{1}, t_{2}$ and $t_{3}$ are reduced with high rates of deformation. A reverse correlation between the model thickness and timing of these moments shows that thicker models are more quickly destroyed; a logical explanation is that the thicker is the model, the larger is the weight of its material, and thus the higher is the rate of its movement downwards by gravitation, and thus the major fracture forms more rapidly.

It can be thus concluded that stages in formation of the strike-slip and normal fault zones are basically manifested in a similar way. However, other conditions being equal, more stages can be identified in strike-slip faulting compared with normal faulting, and this suggests a less complicated mode of evolution of the fracture pattern for formation of faults with hanging block offset on dip.

Spatial aspect of structure development. As evidenced by the fracture density maps (Figures 2 and 4 ), parameter $\rho$ is irregularly distributed. Moreover, the fracture zones of various types as well as other structural elements [Cobbold, Ferguson, 1979; Plotnikov, 1991] are characterized 


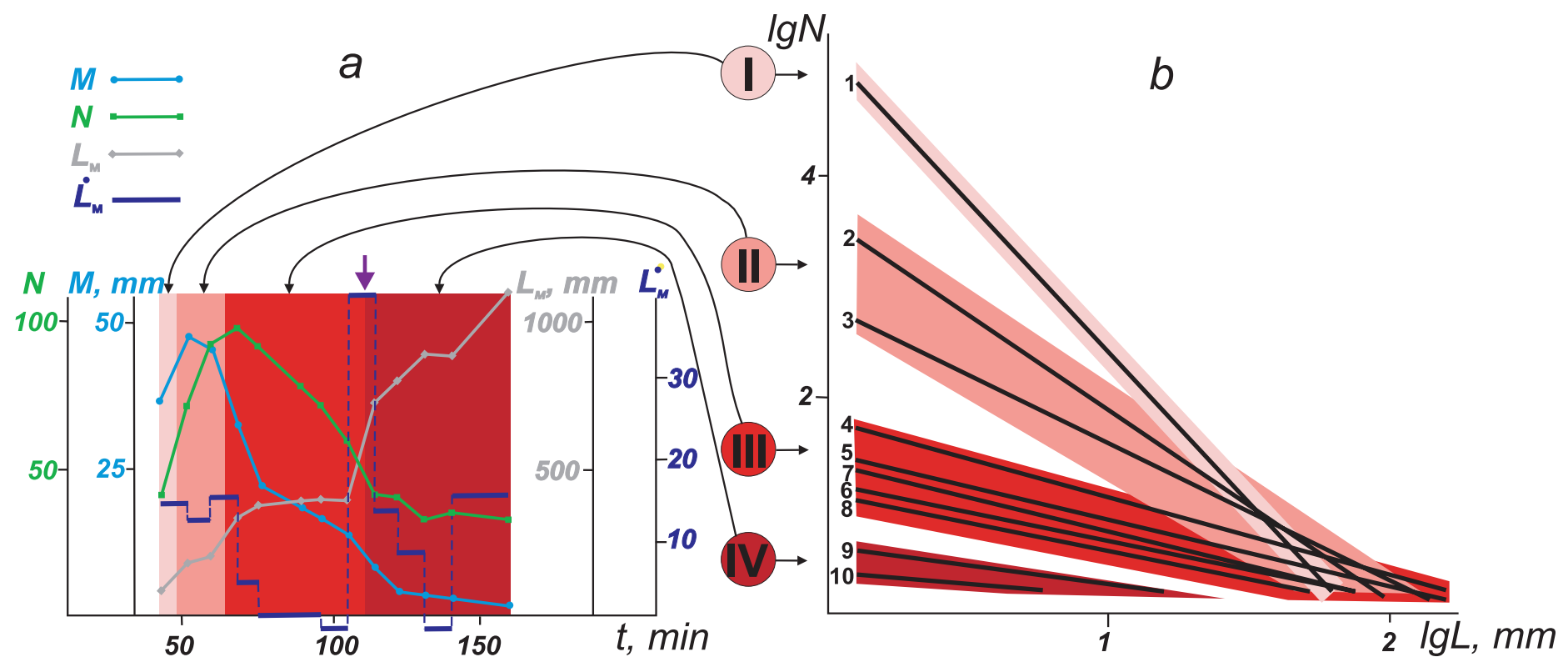

Fig. 3. Results of quantitative analysis of the strike-slip zone in the clay model: $a$ - curves show changes of the zone's width ( $M$ ), fracture quantity $(N)$, maximum fracture length $\left(L_{M}\right)$, and its derivative $\left(L_{M}^{*}\right)$ in time $(t)$; it is possible to distinguish development stages by synchronous variations of the parameters (gradations of grey colour denote stages; the moment of the main structural transformation is marked by an arrow); $b-$ logarithmic dependence curves of fracture quantity $(N)$ and length $(L)$ that provide for identification of stages in development of the strike-slip zone in time (1-10 - stages in time); four stages (I-IV) can be clearly defined.

Рис. 3. Результаты количественного анализа структуры сдвиговой зоны, воспроизведенной в модели из влажной глины: $a-$ графики изменения ширины зоны $(M)$, количества разрывов $(N)$, длины максимального разрыва $\left(L_{M}\right)$ и ее производной $\left(L_{M}^{*}\right)$ во времени $(t)$, позволяющие по синхронным изменениям параметров отделить друг от друга стадии развития сети разрывов (оттенки серого цвета - стадии; момент главной структурной перестройки - стрелка); $b$ - графики логарифмической зависимости количества разрывов $(N)$ от их длины $(L)$, представляющие отдельные временные этапы (1-10) развития сдвиговой зоны и образующие пучки, которые соответствуют четырем стадиям (I-IV).

by the lengthwise regularity of medium deformation: $\rho$ maximums, which alternate with $\rho$ minimums, are located at approximately similar distances from each other. In the shearing zone, the distances between $\rho$ maximums differ from one development stage to another; they tend to increase with time due to deeper penetration of the developing fractures.
Thus, highly fractured areas located at maximum distances from each other are most distinctly manifested at the end of experiment (see Figures 2 and 4). By this time, the zone is clearly dissected lengthwisely into sectors, each being represented by only one fracture, and wide areas of $\rho$ maximums wherein the long-term process of the major fault formation takes place. Such areas should be identified

Experimental parameters and indicative time moments of formation of normal fault zone structure

Параметры, отражающие условия проведения экспериментов и характерные временные моменты формирования структуры сбросовых зон

\begin{tabular}{llllllll}
\hline Experiment No. & $\eta$, Pa·s & $\lambda$, degrees & $H, \mathrm{~mm}$ & $V, \mathrm{~mm} / \mathrm{min}$ & $t_{1}, \min$ & $t_{2}, \mathrm{~min}$ & $t_{3}, \mathrm{~min}$ \\
\hline B-18 & $10^{7}$ & 90 & 120 & 1 & 10 & 30 & 80 \\
B-28 & $10^{7}$ & 90 & 120 & 0.5 & 17 & 48 & 110 \\
B-29 & $10^{7}$ & 90 & 80 & 1 & 25 & 38 & 58 \\
A-6 & $10^{7}$ & 60 & 80 & 1.2 & 4 & 9 & 55 \\
A-7 & $10^{7}$ & 60 & 80 & 11.7 & 4 & 6 & 9 \\
A-13 & $10^{7}$ & 60 & 120 & 11.7 & \\
\hline
\end{tabular}

$\mathrm{N}$ o t e. $\eta$-model material viscosity; $\lambda$ - angle of modelling installation unit's displacement to horizon; $H$ - model thickness; $V$ - deformation rate; $t_{1}$ - time of occurrence of the first fractures, $t_{2}$ - time of main structural transformation, $t_{3}$ - time of occurrence of the major fracture on the model surface.

П р и м е ч а н и е. $\eta$ - вязкость материала модели; $\lambda$ - угол смещения штампа по отношению к горизонту; $H$ - толщина модели; $V$ - скорость деформирования; $t_{1}, t_{2}$ и $t_{3}$ - время проявления на поверхности модели, соответственно, первых разрывов, главной структурной перестройки и магистрального сместителя. 


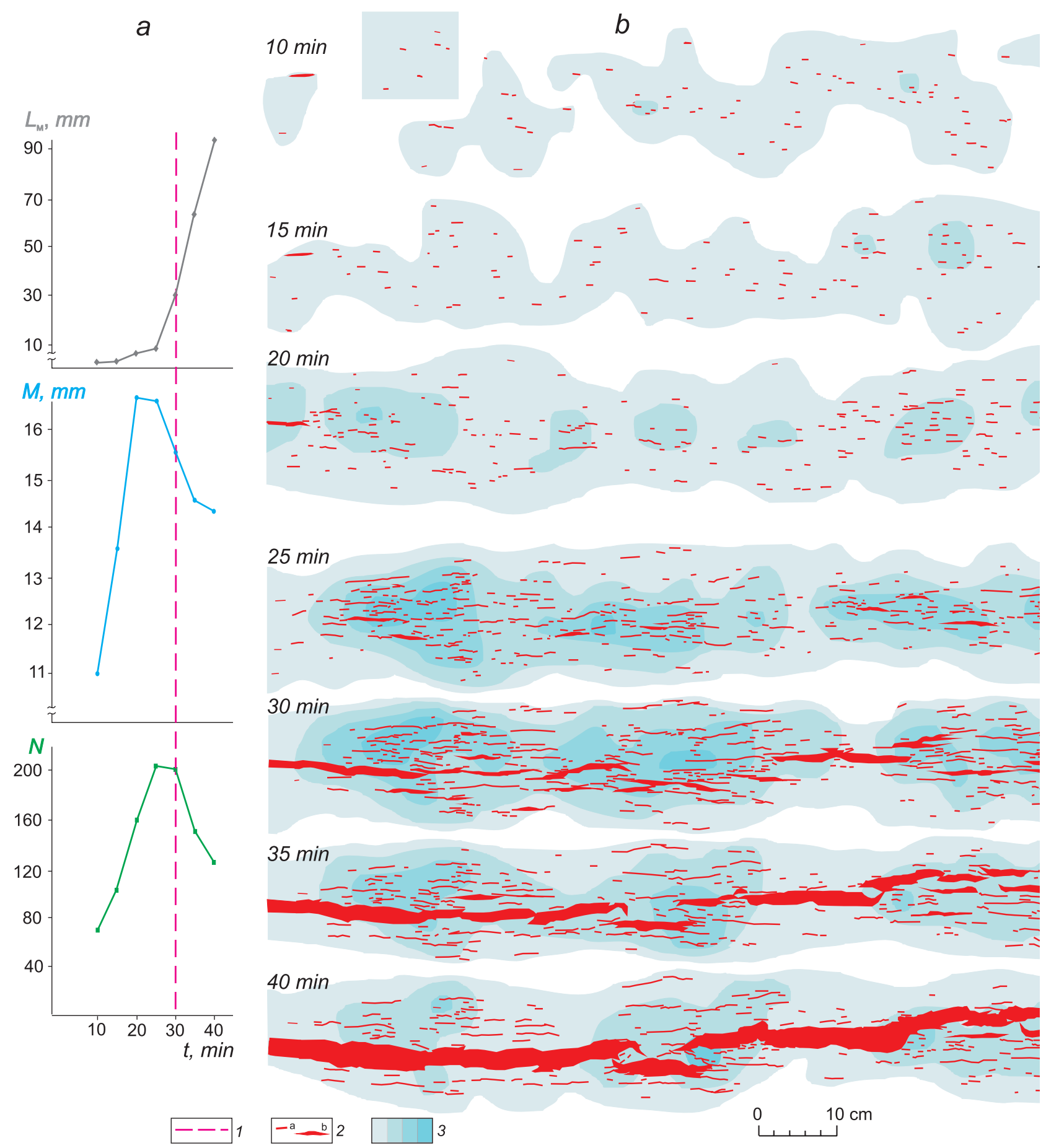

Fig. 4. Curves showing changes of parameters of the fracture pattern in time (a); schemes and density distribution (in isolines) in the normal fault zone are shown in drawing $(b)$ for different steps simulated by the elasto-plastic model. 1 - the moment of the main structural transformation; 2 - fractures with insignificant (a) and significant (b) opening displacement component; 3 - areas of different fracture density; $M$ - average zone width; $N$ - fracture quantity; $L_{M}$ - maximum fracture length; $t$ - time.

Рис. 4. Графики изменения во времени количественных параметров сети разрывов (a), схемы и распределения плотности (в изолиниях) которых в зоне сброса показаны на рисунке $(b)$ для разных этапов деформирования упруго-пластичной модели. 1 - момент главной перестройки в структуре; 2 - разрывы с незначительной (а) и значительной (b) раздвиговой составляющей смещения; 3 - области с различным количеством разрывов в единице площади; $M$ - средняя ширина зоны; $N$ - количество разрывов; $L_{M}-$ длина максимального разрыва; $t$ - время. 
with relay structures which develop firstly to merge with each other into a future major fault, and then its surface gets smoothed during sliding of the fault wings. In the last case, concurrent existence of quite small fractures and the major fault itself within the relay structure is possible for a short period of time (refer to the left-side maximum in two schemes at the bottom of Fig. 4). From the fracture density maps showing the early steps of the modelling, it is difficult to forecast which the neighbouring $\rho$ maximums will belong to the relay structure in the further evolution. Nonetheless, backward tracing of the positions of these structures (from the final to initial steps of the modelling) suggests that they originate from the early steps of faulting (see Figures 2 and 4). Thus, the relay structures reflect the $1^{\text {st }}$ order heterogeneity in distribution of the fractures which is characteristic for certain deformation conditions.

Thus, the $1^{\text {st }}$ order spatial heterogeneity in formation of strike-slip and normal fault zones is demonstrated by the fact that such zones are dissected in the lengthwise direction into sectors of two types. Some sectors, such as relay structures, are lagging behind in development since, within their borders; the segments formed in the neighbouring sectors are merging with each other to form the future major fault. The $2^{\text {nd }}$ and higher order heterogeneities of the medium are represented by the fracture density maximums which are registered when deformation begins and those in relay structures at the final steps of the fault zone evolution.

\section{INTERRELATION OF TEMPORAL AND SPATIAL REGULARITIES IN FORMATION OF THE FAULT ZONE STRUCTURE}

The experimental research of the strike-slip and normal fault zones formed in a variety of deformation conditions of the elasto-plastic model give evidence of the number of general temporal and spatial development regularities. The main regularities established are staging and lengthwise heterogeneity of distribution of fractures.

To define timeframes of the periods when spatial regularities are manifested, specific changes in the structure are referred to; such changes are clearly reflected in external indicators, such as the moment when the single major fault occurs in the zone, or the moment when the main structural transformation starts up. In the schemes showing the post-transformation stages, the sectors are recorded, each represented by a single large active fracture with the largest displacement amplitude (stage 2 in Fig. 2; the 30 minutes stage in Fig. 4). In the adjacent sectors, this displacement amplitude is distributed for many fractures composing the zone. Based on compatibility of the specific fracture patterns and variations in the deformation behaviour of the loaded massif, it is possible to distinguish three stages of fault zone development which are marked out by the moments of the main structural transformation start-up and the occurrence of the major fault. With such an ap- proach, the stages defined above on the basis of the quantitative evaluations of the fracture patterns should be classified as sub-stages which reflect sequential formation of large fractures, resulting from merging of small fractures in the course of structural transformations.

The main stages are basically similar to the three stages defined for shearing zones in the recent studies [Tchalenko, 1970]; in some reports, such stages are referred to when faulting is described [Ben-Zion, Sammis, 2003]. The data collected in our experiments provide for development of this concept and allow us to establish the multi-level staging mode and to propose the new criterion for identification of stages 1 and 2, and also to obtain comprehensive characteristics of such stages. In this logic, our tectonophysical model of faulting is presented below in the format of consecutive characteristics of the three main stages, each with its peculiar medium behaviour in terms of deformation, and its specific spatial and temporal variations of the parameters of the fracture pattern.

The early stage of the fault development (see Fig. 2) refers to the zone of several fracture systems, the most developed of which are $R$-type synthetic fractures. The fracture patterns evolves irregularly (i.e. in sub-stages), with the overall strengthening of the medium of the fault zone. The zone's width and the numbers of active fractures in the zone increase intensively and then decrease with time. The length of the longest fracture in the zone increases irregularly throughout this stage. The lengthwise distribution of no-contrast maximums of the fracture density is regular; such maximums are located close to each other as only the near-surface layer is subjected to destruction.

The late stage of the fault development (see Fig. 2) refers to the zone of lengthy $R$-shears; the longest $R$-shears are located in some sectors as the single fractures; whereas in the neighbouring areas they conjugate to form $R-, P$-, and $Y$-type fractures. The zone's width is considerably variable in the lengthwise direction; it decreases with time; the number of active faults decreases with time too. Along with the accelerated increase of the longest fracture, this reflects localization of deformation, while the strength of the loaded volume is ceasing. This process is irregular in time, and sub-stages are possible. The distribution of the fracture density can be characterized by the lengthwise regularity as given by the distinct differentiation of the zone into intensively fractured sectors wherein the relay structures develop (2 in Fig. 2) and the adjacent areas wherein practically the whole displacement amplitude is released by a single large fracture (1 in Fig. 2). The distances between the fracture density maximums reflect the $1^{\text {st }}$ order destruction heterogeneity for the given conditions of deformation.

The stage of complete destruction refers to the single major fault and feathering fractures which are mainly associated with the given fault's bends (see Fig. 2) and formed in conditions of lengthwise compression or extension. The zone's width and the number of fractures within its limits are tending to the minimum; the length of the 


longest fracture depends on the dimensions of the volume being destructed. Even upon the formation of the plane surface of the fault, this volume maintains a residual strength; therefore, the term of «complete destruction» can only be applicable as to reflect the fact that the volume subject to deformation is dissected by the single fault represented by faulted rocks.

According to the indicators considered above, the north-eastern strike-slip segment of the Baikal rift zone (Fig. 5, a) [Logatchev et al., 1983] can exemplify the early stage of development of strike-slip fault zones. The same refers to numerous, so-called latent (or dispersed) faults which represent the zones of the Riedel shears in the sedimentary cover in the course of the foundation blocks' movements [Gzovsky, 1975; Makarov, Shchukin, 1979; Koronovsky et al., 2009]. The North-Anatolian (Fig. 5, b) [Chorowicz et al., 1999] and the Alpine [Norris, Cooper, 2003] strike-slip faults can be classified as faults in the late stage of development. The San-Andreas (Fig. 5, c) [Kim, Sanderson, 2004] and the Dead Sea [Garfunkel, BenAvraham, 1996] transform faults can be classified as those in the stage of complete destruction. Board structures of the Sicilo-Calabrian (South Italy) [Monaco, Tortorici, 2000] and the Corinth (Greece) Rifts (Fig. 5, d) [Moretti et al., 2003], and others fault systems are lengthy normal fault zones in the early development stage. The West Sinai fault zone (Fig. 5, e) [Knott et al., 1996] and the Wasatch fault zone in the Basin and Range province [Smith, Bruhn, 1984] are in the late development stage. Board structures of the Rhine graben (Fig. 5, f) [Andre et al., 2001], the Primorskiy normal fault in the Baikal rift [Logatchev et al., 1983], and other faults are in the stage of complete destruction.

It should be noted that the spatial and temporal regularities considered above are characteristic for faults of different types and scales. The lengthwise regularity of deformation of the fault zone medium, that is the general property of deformation distribution in homogeneous bodies [Cobbold, Ferguson, 1979; Plotnikov, 1991], is manifested in relatively ideal conditions of analogue [Clifton, Schlische, 2001] and numerical [Stephen et al., 1998] modelling, yet this regularity is discovered for some natural objects (Fig. 5). The three main stages in the development of large strike-slip faults and normal faults can be identified in the development of mesofaults, as, for instance, it can be yielded from the analysis of the block diagrams for strike-slip faults in [Kim et al., 2003] and for normal faults in [Walsh et al., 2003]. It is reasonable to suggest that the regularities may be valid for intermediate scales due to self-similarity of the process described in [Kim et al., 2003; Kim, Sanderson, 2004]. The spatial and temporal regularities typical of strike-slip and normal faulting may be typical of reverse faulting in mode II. All the three cases of faulting are characterised by the common peculiarity concerning loading when positioning of the fault zone is predetermined by the plane of blocks' interaction.

Thus, the established spatial and temporal regularities 
of fault zone structure formation are characterized by high level of generalization. It is reasonable to assume that these regularities can be manifested by the same external indicators at faults which evolve in similar loading conditions with the elasto-plastic behaviour of the medium. At the same time, the manifestation of these regularities in natural environment is definitely complicated by nonhomogeneities of the structure and material composition of the earth crust, and in term of quantity, by variations of deformation conditions.

\section{CONCLUSIONS}

The experimental research of shearing zones which occur in mode II (normal faults) and mode III (strike-slip faults) show that their formation takes place according to the general temporal and spatial formation regularities. These regularities are integrated in the structure formation and reflect the heterogeneity, being the fundamental property of destruction, which is manifested even in the stable mode of deformation.

The temporal heterogeneity is reflected in staging of the evolution of the fault zones, and such evolution stages fall into two levels. The $1^{\text {st }}$ level includes the three main stages, i.e. the early and late stages and the stage of com- plete destruction; each of these stages corresponds to particular behaviour of the medium subjected to deformation and a particular fault pattern. The $2^{\text {nd }}$ level includes substages separated by structural transformations when fractures of larger scales are formed.

The spatial heterogeneity is manifested by the existence of sectors with higher and lower fracture densities; such sectors are typically alternating along the strike of shearing zones and located at a specific distance from each other. During the structure evolution, the distance between these sectors increases; finally, relay structures reflect the spatial destruction heterogeneity of the $1^{\text {st }}$ order. In this aspect, the lengthwise regularity is essential for formation of fault zones; anyway, the rock massive heterogeneities impose certain complications (sometimes significant ones) on the way how this regularity is manifested in natural environment.

The above discussed temporal and spatial regularities of fracturing are consolidated in the tectonophysical model of a fault zone; this model provides a sequential description of the characteristics of the three main stages of development of the fault zone. The early and late stages and the stage of complete destruction are characterized by specific behaviour of the medium due to deformation, peculiar status and development of the fracture patterns, as reflected in specific variations of its main parameters.

\section{REFERENCES}

Ackermann R.V., Schlische R.W., Withjack M.O., 2001. The geometric and statistical evolution of normal fault systems: an experimental study of the effects of mechanical layer thickness on scaling laws. Journal of Structural Geology 23 (11), 1803-1819. http://dx.doi.org/10.1016/S0191-8141(01)00028-1.

Andre A.S., Sausse J., Lespinasse M., 2001. New approach for the quantification of paleostress magnitudes: application to the Soultz vein system (Rhine, France). Tectonophysics 336 (1-4), 215-231. http://dx.doi.org/10.1016/S0040-1951(01) 00103-2.

Bartlett W.L., Friedman M., Logan J.M., 1981. Experimental folding of rocks under confining pressure. Part IX: wrench faults in limestone layers. Tectonophysics 79 (3-4), 255-277. http://dx.doi.org/10.1016/0040-1951(81)90116-5.

Ben-Zion Y., Sammis C.G., 2003. Characterization of fault zones. Pure and Applied Geophysics 160 (3-4), 677-715. http:// dx.doi.org/10.1007/PL00012554.

Chorowicz J., Dhont D., Gundogdu N., 1999. Neotectonics in the eastern North Anatolian fault region (Turkey) advocates crustal extension: mapping from SAR ERS imagery and Digital Elevation Model. Journal of Structural Geology 21 (5), 511-532. http://dx.doi.org/10.1016/S0191-8141(99)00022-X.

Clifton A.E., Schlische R.W., 2001. Nucleation, growth, and linkage of faults in oblique rift zones: Results from experimental clay models and implications for maximum fault size. Geology 29 (5), 455-458. http://dx.doi.org/10.1130/0091-7613 (2001)029<0455:NGALOF>2.0.CO;2.

Cobbold P.R., Ferguson C.C., 1979. Description and origin of spacial periodicity in tectonic structures: report on a Tectonic Studies group Conference held at Nottingam University. November, 1978. Journal of Structural Geology 1 (1), 93-97. http://dx.doi.org/10.1016/0191-8141(79)90025-7.

Garfunkel Z., Ben-Avraham Z., 1996. The structure of the Dead Sea Basin. Tectonophysics 226 (1-4), 155-176. http://dx. doi.org/10.1016/S0040-1951(96)00188-6.

Gibbs A.D., 1984. Structural evolution of extensional basin margins. Journal of the Geological Society 141 (4), 609-620. http://dx.doi.org/10.1144/gsjgs.141.4.0609.

Guohai J., Groshong Jr. R.H., 2006. Trishear kinematic modeling of extensional fault-propagation folding. Journal of Structural Geology 28 (1), 170-183. http://dx.doi.org/10.1016/j.jsg.2005.09.003.

Gzovsky M.V., 1975. Fundamentals of Tectonophysics. Nauka, Moscow, 536 p. (in Russian) [Гзовский М.В. Основы тектонофизики. М.: Наука, 1975. 536 с.]. 
Kearey P. (Ed.), 1993. The encyclopedia of the solid Earth sciences. Backwell Science, Oxford, 713 p.

Kim Y.-S., Peacock D.C.P., Sanderson D.J., 2003. Mesoscale strike-slip faults and damage zones at Marsalforn, Gozo Island, Malta. Journal of Structural Geology 25 (5), 793-812. http://dx.doi.org/10.1016/S0191-8141(02)00200-6.

Kim Y.-S., Peacock D.C.P., Sanderson D.J., 2004. Fault damage zones. Journal of Structural Geology 26 (3), $503-517$. http://dx.doi.org/10.1016/j.jsg.2003.08.002.

Kim Y.-S., Sanderson D.J., 2004. Similarities between strike-slip faults at different scales and a simple age determining method for active faults. The Island Arc 13 (1), 128-143. http://dx.doi.org/10.1111/j.1440-1738.2003.00410.x.

Knott S.D., Beach A., Brockbank P.J., Brown J.L., McCallum J.E., Welbon A.I., 1996. Spatial and mechanical controls on normal fault populations. Journal of Structural Geology 18 (2-3), 359-377. http://dx.doi.org/10.1016/S0191-8141(96) 80056-3.

Koronovsky N.V., Gogonenkov G.N., Goncharov M.A., Timurziev A.I., Frolova N.S., 2009. Role of shear along horizontal plane in the formation of helicoidal structures. Geotectonics 43 (5), 357-379. http://dx.doi.org/10.1134/S0016852109 050033.

Lobatskaya R.M., 1987. Structural zonation of faults. Nedra, Moscow, 128 p. (in Russian) [Лобацкая Р.М. Структурная зональность разломов. М.: Недра, 1987. 128 с.].

Logatchev N.A. (Ed.), Levi K.G., Plyusnina L.V., Sherman S.I., 1983. The map of neotectonics of the Baikal-Amur Railway Region. Scale 1:3,000,000. Irkutsk (in Russian) [Логачев Н.А. (ред.), Леви К.Г., Плюснина Л.В., Шерман С.И. Карта неотектоники региона Байкало-Амурской магистрали. Масштаб 1:3000000. Иркутск, 1983].

Makarov V.I., Shchukin Yu.K., 1979. Hidden fault activity assessment. Geotektonika 1, 96-109 (in Russian) [Макаров В.И., Шукин Ю.К. Оценка активности скрытых разломов // Геотектоника. 1979. № 1. С. 96-109]

Mandl G., 1988. Mechanics of tectonic faulting. Models and basic concepts. Elsevier, Amsterdam, 407 p.

Mikhailova A.V., 1971. The method of quantitative analysis of displacements, deformation and stresses in plastic nontransparent models. In: Tectonophysics and Mechanical Properties of Rocks. Nauka, Moscow, p. 38-48 (in Russian) [Михайлова А.В. Методика количественной оценки перемещений, деформаций и напряжений в пластических непрозрачных моделях // Тектонофизика и механические свойства горных пород. М.: Наука, 1971. С. 38-48].

Monaco C., Tortorici L., 2000. Active faulting in the Calabrian arc and eastern Sicily. Journal of Geodynamics 29 (3-5), 407-424. http://dx.doi.org/10.1016/S0264-3707(99)00052-6.

Moretti I., Sakellariou D., Lykousis V., Micarelli L., 2003. The Gulf of Corinth: an active half graben? Journal of Geodynamics 36 (1-2), 323-340. http://dx.doi.org/10.1016/S0264-3707(03)00053-X.

Norris R.J., Cooper A.F., 2003. Very high strains recorded in mylonites along the Alpine Fault, New Zealand: Implications for the deep structure of plate boundary faults. Journal of Structural Geology 25 (12), 2141-2157. http://dx.doi.org/10. 1016/S0191-8141(03)00045-2.

Park R.G., 1997. Foundations of structural geology. Chapman \& Hall, London, 202 p.

Plotnikov L.M., 1991. Shear structures in laminated geological bodies. Nedra, Leningrad, 151 p. (in Russian) [Плотников Л.М. Структуры сдвига в слоистых геологических телах. Л.: Недра, 1991. 151 с.].

Rosas F.M., Duarte J.C., Terrinha P., Valadares V., Matias L., 2009. Morphotectonic characterization of major bathymetric lineaments in Gulf of Cadiz (Africa-Iberia plate boundary): Insights from analogue modelling experiments. Marine Geology 261 (1-4), 33-47. http://dx.doi.org/10.1016/j.margeo.2008.08.002.

Seminsky K.Zh., 1990. General regularities of dynamics of structure formation in the large shear zones. Geologiya i Geofizika (Russian Geology and Geophysics) 4, 14-23 (in Russian) [Семинский К.Ж. Общие закономерности динамики структурообразования в крупных сдвиговых зонах // Геология и геофизика. 1990. № 4. С. 14-23].

Sherman S.I., Bornyakov S.A., Buddo V.Yu., 1983. Areas of dynamic influence of faults (modelling results). Nauka, Novosibirsk, 112 p. (in Russian) [Шерман С.И., Борняков С.А., Буддо В.Ю. Области динамического влияния разломов (результаты моделирования). Новосибирск: Наука, 1983. 112 с.].

Smith R.B., Bruhn R.L., 1984. Intraplate extensional tectonics of the eastern Basin-Range: inferences on structural style from seismic reflection data, regional tectonics, and thermal-mechanical models of brittle-ductile deformation. Journal of Geophysical Research 89 (B7), 5733-5762. http://dx.doi.org/10.1029/JB089iB07p05733.

Stephen D., McKinnon S.D., Barra I.G., 1998. Fracture initiation, growth and effect on stress field: a numerical investigation. Journal of Structural Geology 20 (12) 1673-1689. http://dx.doi.org/10.1016/S0191-8141(98)00080-7.

Sylvester A.G., 1988. Strike-slip faults. Geological Society of America Bulletin 100 (11), 1666-1703. http://dx.doi.org/10. 1130/0016-7606(1988)100<1666:SSF>2.3.CO;2.

Tchalenko J.S., 1970. Similarities between shear zones of different magnitudes. Geological Society of America Bulletin 81 (6), 1625-1640. http://dx.doi.org/10.1130/0016-7606(1970)81[1625:SBSZOD]2.0.CO;2.

Walsh J.J., Childs C., Imber J., Manzocchia T., Wattersonb J., Nellc P.A.R., 2003. Strain localization and population changes during fault system growth within the Inner Moray Firth, Northern North Sea. Journal of Structural Geology 25 (2), 307-315. http://dx.doi.org/10.1016/S0191-8141(02)00028-7. 
Walsh J.J., Watterson J., Bailey W.R., Childs C., 1999. Fault relays, bends and branch-lines. Journal of Structural Geology 21 (8-9), 1019-1026. http://dx.doi.org/10.1016/S0191-8141(99)00026-7.

Wilcox R.E., Harding T.P., Seely D.R., 1973. Basic wrench tectonics. American Association of Petroleum Geologists Bulletin 57 (1), 74-96. http://dx.doi.org/10.1306/819A424A-16C5-11D7-8645000102C1865D.

Woodcock N.H., Fischer M., 1986. Strike-slip duplexes. Journal of Structural Geology 8 (7), 725-735. http://dx.doi.org/10. 1016/0191-8141(86)90021-0.

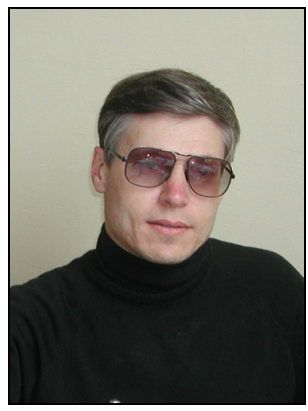

Семинский Константин Жанович, докт. геол.-мин. наук, зав. лабораторией тектонофизики Институт земной коры СО РАН

664033, Иркутск, ул. Лермонтова, 128, Россия

Тел.: 8(3952)423027; \ e-mail: seminsky@crust.irk.ru

Seminsky, Konstantin Zh., Doctor of Geology and Mineralogy, Head of Laboratory of Tectonophysics Institute of the Earth's Crust, Siberian Branch of RAS

128 Lermontov street, Irkutsk 664033, Russia

Tel.: 8(3952)423027; $\$ e-mail: seminsky@crust.irk.ru 